\title{
EFEKTIVITAS PENERAPAN PERATURAN MAHKAMAH AGUNG REPUBLIK INDONESIA NOMOR 2 TAHUN 2015 (PERMA NO. 2 TAHUN 2015) TENTANG TATA CARA PENYELESAIAN GUGATAN SEDERHANA DALAM PENYELESAIAN PERKARA PERDATA
}

(Studi di Pengadilan Negeri Kabupaten Kediri)

\author{
Wiryatmo Lukito Totok \\ Pengadilan Negeri Kabupaten Kediri \\ Email: mizanjurnalilmuhukum@gmail.com
}

\begin{abstract}
ABSTRAK
Sesuai Peraturan Presiden RI No 2 Tahun 2015 tentang Rencana Pembangunan Jangka Menengah Nasional (RPJMN) 2015-2019 mengamanatkan untuk melaksanakan Reformasi Sistem Hukum Perdata yang Mudah dan Cepat, merupakan upaya untuk meningkatkan daya saing perekonomian nasional. Dalam rangka mewujudkan daya saing tersebut, pembangunan hukum nasional perlu diarahkan untuk mendukung terwujudnya pertumbuhan ekonomi yang berkelanjutan; mengatur permasalahan yang berkaitan dengan ekonomi, terutama dunia usaha dan industri; serta menciptakan kepastian investasi, terutama penegakan dan perlindungan hukum. Oleh karena itu diperlukan strategi secara sistematis terhadap revisi peraturan perundang-undangan di bidang hukum perdata secara umum maupun khusus terkait hukum kontrak, perlindungan HaKI, pembentukan penyelesaian sengketa acara cepat (small claim court), dan peningkatan utilisasi lembaga
\end{abstract} mediasi.

Merespon hal tersebut, sesuai kewenangan yang dimilikinya, Mahkamah Agung mencoba menjawab kekosongan hukum dan hal-hal yang belum cukup diatur dalam Undang-Undang (UU) karena didasarkan atas pertimbangan bahwa hukum acara perdata yang ada sekarang baik HIR ataupun RBg belum mengadopsi tentang prinsip gugatan sederhana sedangkan RUU KUHPerdata sampai sekarang pun belum juga dibahas oleh DPR sehingga akhirnya Mahkamah Agung merasa perlu untuk mengeluarkan PERMA untuk mengisi kebutuhan hukum.

Tujuan dalam penelitian ini adalah: 1.untuk menganalis penerapan Peraturan Mahkamah Agung Republik Indonesia Nomor 2 Tahun 2015 (PERMA No. 2 Tahun 2015) tentang Tata Cara Penyelesaian Gugatan Sederhana dalam menyelesaian perkara perdata; dan 2. untuk mengetahui faktor-faktor yang mempengaruhi penerapan Peraturan Mahkamah Agung Republik Indonesia Nomor 2 Tahun 2015 (PERMA No. 2 Tahun 2015) tentang Tata Cara Penyelesaian Gugatan Sederhana

Penelitian ini menggunakan jenis penelitian yuridis empiris, sumber data dalam penelitian ini adalah sumber data primer dan sumber data sekunder. Teknik pengumpulan data dengan cara melakukan kuesi wawancara dengan para Hakim dan para Aparatur Pengadilan yang terkait dengan rumusan masalah ini serta melakukan survei terhadap responden dalam hal ini masyarakat para pengguna layanan serta pencari keadilan pada Pengadilan Negeri Kabupaten Kediri, dengan metode kuantitatif dan sampel diambil dengan teknik simple random sampling dengan harapan mampu memberikan gambaran mengenai Tentang Efektivitas Penerapan Peraturan Mahkamah Agung Nomor 2 Tahun 2015 tentang Tata Cara Penyelesaian Gugatan Sederhana dalam rangka penyelesaian perkara perdata dipengadilan.

Hasil penelitian ini adalah: 1. Penerapan Peraturan Mahkamah Agung (PERMA) Nomor 2 Tahun 2015 tentang Tata Cara Penyelesaian Gugatan Sederhana dalam Rangka Penyelesaian Perkara Perdata dipengadilan menurut hasil wawancara dengan para Hakim dan para Aparatur Pengadilan didapatkan hasil bahwa prosedur gugatan sederhana sangat efektif serta sesuai dengan asas sederhana, cepat dan biaya ringan serta dari survei didapatkan bahwa Indeks survei Efektivitas Penerapan PERMA No. 2 tahun 2015 Tentang Gugatan Sederhana di Pengadilan Negeri Kabupaten Kediri Kelas I B adalah sebesar 64,53 \% berada pada kategori "BAIK" (pada interval $62.51 \mathrm{~s} / \mathrm{d} 81.25)$.

dan 2. Faktor-faktor yang mempengaruhi penerapan terhadap Tata Cara Penyelesaian Gugatan Sederhana : a. Faktor Peraturan Perundang-undangan, b. Faktor Budaya Hukum 
Masyarakat, c. Faktor Aparat Penegak Hukum dan d. Faktor Pengetahuan Masyarakat tentang PERMA No.2 Tahun 2015

Kata Kunci: efektivitas, gugatan sederhana.

\section{ABSTRACT}

In accordance with Presidential Regulation No. 2 of 2015 on the National Medium Term Development Plan (RPJMN) 2015-2019 mandated to implement the Reformation of the Easy and Fast Civil Law System, is an effort to improve the competitiveness of the national economy. In order to realize the competitiveness, the development of national law should be directed to support the realization of sustainable economic growth; Regulating issues related to the economy, especially business and industry; As well as create investment certainty, especially enforcement and legal protection. Therefore, a systematic strategy is needed to revise legislation in civil law in general and in particular with respect to contract law, protection of intellectual property rights, the establishment of a small claim, and increased utilization of mediation institutions.

Responding to this matter, in accordance with its authority, the Supreme Court tries to answer the legal vacuum and matters that are not sufficiently regulated in the Act because it is based on the consideration that the existing civil law law, whether HIR or RBG has not adopted the principle of small claim while the Civil Code bill until now also has not been discussed by the Parliament so that the Supreme Court finally felt the need to issue PERMA to fill legal needs.

The aims of this research are: 1. to analyze the application of Regulation of The Supreme Court (PERMA) Number 2 of 2015 Concerning Procedure on Settlement of Small Claim; And 2. to know the factors influencing the application of Regulation of The Supreme Court (PERMA) Number 2 of 2015 Concerning Procedure on Settlement of Small Claim.

This research uses the type of juridical empirical research, data sources in this research are primary data sources and secondary data sources. Technique of collecting data by doing kuesi interview with Judges and Court Officials related to the formulation of this problem and do survey to respondent in this case community of service user and justice seeker at Kediri District Court, with quantitative method and sample taken by technique simple random sampling in the hope of providing an overview on the effectiveness of Regulation of The Supreme Court (PERMA) Number 2 of 2015 Concerning Procedure on Settlement of Small Claim in the context of the settlement of civil cases in court.

The results of this research are: 1. Application of Supreme Court Regulation (PERMA) No. 2 of 2015 Concerning Procedure on Settlement of Small Claim in Civil Case in accordance with the results of interviews with the Judges and Court Officials obtained the result that the small claim procedure is very effective and in accordance with Simple principles, fast and light cost and from the survey it was found that PERMA number 2 of 2015 Application Performance Effectiveness Index about small claim at Kediri District Court Class I B is 64,53\% in "GOOD" category (at interval 62.51 s / d 81.25). And 2. Factors affecting the application to the Procedures for Settlement of small claim: a. Factor of Laws Regulation, b. Community Legal Cultural Factors, c. Factors of Law Enforcement Officers and d. Community Knowledge Factor about PERMA No.2 of 2015.

Keywords: effectiveness, small claim.

\section{A. PENDAHULUAN}

Istilah gugatan sederhana merupakan sesuatu yang baru didalam sistem hukum kita namun demikian sesungguhnya adalah bukan hal yang baru dan telah dikembangkan baik di negara-negara yang berlaku sistem Common Law maupun sistem Civil Law dengan nama Small Claim Court.

Small Claim Court telah tumbuh dan berkembang pesat tidak hanya di negaranegara maju seperti Amerika, Kanada, Inggris, Jerman, Belanda, tapi juga di Amerika Latin, Afrika dan juga Asia dengan istilah Small Claim Court/SCC.
Konsep small claims court adalah badan hukum yang dimaksudkan untuk memberikan solusi yang cepat dan ekonomis untuk menyelesaikan sengketa yang tidak membutuhkan biaya yang mahal. Small claims court merupakan forum penyelesaian sengketa yang bersifat informal dan biaya perkara yang relatif lebih murah, dengan nilai perkara yang kecil. 1 Hal ini sejalan dengan maksud

\footnotetext{
${ }^{1}$ Francis Ward Stephanie, Oktober 2011 "Small Claims Court the "Fast Food" of the Legal
} 
dibentuknya small claims court, yakni untuk menyediakan formalitas penyelesaian sengketa dengan nilai gugatan yang kecil pemeriksaan perkara yang tidak rumit untuk menyelesaikan sengketa yang bersifat sederhana yang tidak membutuhkan uang yang banyak untuk menjamin biaya litigasi formal. ${ }^{2}$

Bagaimana dengan pemberlakukan small claims di Indonesia, maka sesuai Rencana Pembangunan Jangka Menengah Nasional (RPJMN) 2015-2019 mengamanatkan untuk melaksanakan Reformasi Sistem Hukum Perdata yang Mudah dan Cepat, merupakan upaya untuk meningkatkan daya saing perekonomian nasional. Dalam rangka mewujudkan daya saing tersebut, pembangunan hukum nasional perlu diarahkan untuk mendukung terwujudnya pertumbuhan ekonomi yang berkelanjutan; mengatur permasalahan yang berkaitan dengan ekonomi, terutama dunia usaha dan industri; serta menciptakan kepastian investasi, terutama penegakan dan perlindungan hukum. Oleh karena itu diperlukan strategi secara sistematis terhadap revisi peraturan perundang-undangan di bidang hukum perdata secara umum maupun khusus terkait hukum kontrak, perlindungan HaKI, pembentukan penyelesaian sengketa acara cepat (small claim court), dan peningkatan utilisasi lembaga mediasi ${ }^{3}$.

Merespon hal tersebut, sesuai kewenangan yang dimilikinya, Mahkamah Agung mencoba menjawab kekosongan hukum dan hal-hal yang belum cukup diatur dalam Undang-Undang (UU) karena didasarkan atas pertimbangan bahwa hukum

System", American Bar Assiciation Journal, Vol. 9, No. 2,h. 93.

2 Efa Laela Fakhriah, Eksistensi Small Claim Court dalam Mewujudkan Tercapainya Peradilan Sederhana, Cepat, dan Biaya Ringan. Hasil Penelitian Mandiri tahun 2012. Dosen Fakultas Hukum Universitas Padjadjaran Bandung pada mata kuliah Hukum Acara Perdata, Hukum Penyelesaian Sengketa, Hukum Kesehatan., h.10-12.

3 Peraturan Presiden RI No 2 Tahun 2015 tentang Rencana Pembangunan Jangka Menengah Nasional (RPJMN) 2015- 2019 BUKU I Agenda Pembangunan Nasional, Kementerian Perencenaan Pembangunan Nasional/ Badan Perencanaan Pembangunan Nasional 2014. acara perdata yang ada sekarang baik HIR ataupun $\mathrm{RBg}$ belum mengadopsi tentang prinsip gugatan sederhana sedangkan RUU KUHPerdata sampai sekarang pun belum juga dibahas oleh DPR sehingga akhirnya Mahkamah Agung merasa perlu untuk mengeluarkan PERMA untuk mengisi kebutuhan hukum.

Diawali dengan pembentukan Kelompok Kerja (Pokja) Penyusunan PERMA Penyelesaian Perkara Gugatan Sederhana berdasarkan SK KMA No. 267/KMA/SK/X/20134',hingga akhirnya diterbitkan Peraturan Mahkamah Agung Nomor 2 Tahun 2015 tentang Tata Cara Penyelesaian Gugatan Sederhana (PERMA Nomor 2 Tahun 2015) yang secara efektif telah dilaksanakan oleh seluruh pengadilan tingkat pertama sejak diundangkan pada tanggal 7 Agustus 2015 dalam Berita Negara Republik Indonesia Tahun 2015 Nomor 1172, dengan menggunakan nama gugatan sederhana dan memiliki karesteristik yang tidak berbeda jauh Small Claim Court yang berlaku dibeberapa negara namun disesuaikan dengan kondisi yang ada di Indonsia.

Gugatan sederhana PERMA Nomor

2 Tahun 2015 merumuskan sebagai perkara cidera janji dan/atau perbuatan melawan hukum dengan nilai gugatan materil paling banyak Rp. 200.000.000,00 (dua ratus juta rupiah), yang diselesaikan dengan tata cara dan pembuktian sederhana.

\section{B. METODE PENELITIAN}

a. Lokasi Penelitian

Lokasi penelitian adalah tempat yang digunakan dalam melaksanakan penelitian untuk memperoleh data yang diinginkan. Penelitian dilaksanakan di Pengadilan Negeri Kabupaten Kediri di Jalan Pamenang Nomor 60, Kecamatan Ngasem, Kabupaten Kediri.

b. Desain dan Variabel Penelitian

Spesifikasi penelitian adalah deskriptif analitis yang bertujuan untuk

4 Direktorat Jenderal Badan Peradilan Umum Mahkamah Agung RI,2015, Bimbingan Teknis Penyelesaian Perkara Gugatan Sederhana, Direktorat Jenderal Badan Peradilan Umum Mahkamah Agung RI 
memperoleh gambaran yang menyeluruh mengenai efektivitas penerapan PERMA No. 2 Tahun 2015 Tentang Tata Cara Penyelesaian Gugatan Sederhana sebagai mekanisme penyelesaian sengketa perdata yang memerlukan penyelesaian dengan cepat, sederhana dan murah. Data yang diperoleh kemudian akan dianalisis secara campuran antara kuatitatif dan kualitatif, kemudian hasil analisis dideskripsikan dalam bentuk laporan penelitian.

c. Populasi dan Sampel

Metode pengambilan sampel yang digunakan dalam penelitian ini adalah dengan menggunakan simple random sampling dengan populasi penelitian ini adalah semua masyarakat para pengguna layanan serta pencari keadilan pada Pengadilan Negeri Kabupaten Kediri I B.

\section{d. Pengumpulan Data}

1. Penelitian Kepustakaan / Metode Penelitian Normatif

Penelitian kepustakaan dilaksanakan oleh penulis dengan cara mengumpulkan semua data yang berkaitan dengan masalah yang diangkat, yang terdapat di dalam literatur-literatur, buku-buku, makalah-makalah, media massa, media elektronik, dan peraturan perundang - undangan, serta putusan pengadilan

2. Penelitian Lapangan / Metode Penelitian Empiris

Penelitian empiris adalah penelitian yang melakukan pengujian mengenai sejauhmana teori hukum dapat diterapkan didalam suatu masyarakat tertentu dan apakah aturan-aturan hukum tertentu dipatuhi oleh pemegang peran dalam hidup bermasyarakat. Penelitian hukum yang menggunakan pendekatan empirik mengkaji mengenai ha-hal sebagai berikut: hukum dipandang sebagai perintah melakukan atau larangan melakukan sesuatu yang disertai sanksi agar perintah atau larangan tersebut ditaati ${ }^{5}$. Penelitian lapangan dilaksanakan dengan cara melakukan kuesi wawancara dengan para Hakim dan para Aparatur Pengadilan yang terkait dengan rumusan masalah ini serta melakukan survei terhadap responden dalam hal ini masyarakat para pengguna layanan serta pencari keadilan pada Pengadilan Negeri Kabupaten Kediri, dengan metode kuantitatif dan sampel diambil dengan teknik simple random sampling dengan harapan mampu memberikan gambaran mengenai Tentang Efektivitas Penerapan Peraturan Mahkamah Agung Nomor 2 Tahun 2015 tentang Tata Cara Penyelesaian Gugatan Sederhana dalam rangka penyelesaian perkara perdata dipengadilan.

\section{e. Analisis Data}

Analisa data akan dilaksanakan oleh penulis dengan cara data diperoleh dari penelitian normatif dan empiris dan dianalisa secara campuran antara kuatitatif dan kualitatif dengan pendekatan yuridis normatif empiris.

Spesifikasi penelitian adalah deskriptif analitis yang bertujuan untuk memperoleh gambaran yang menyeluruh mengenai efektivitas penerapan PERMA No. 2Tahun 2015 Tentang Tata Cara Penyelesaian Gugatan Sederhana sebagai mekanisme penyelesaian sengketa perdata yang memerlukan penyelesaian dengan cepat, sederhana dan murah. Data yang diperoleh kemudian akan dianalisis secara campuran antara kuatitatif dan kualitatif, kemudian hasil analisis dideskripsikan dalam bentuk laporan penelitian.
5 Peter Mahmud Marzuki,2009, Penelitian Hukum, Kencana Prenada Media Group, Jakarta, h.93. 


\section{PEMBAHASAN}

Penerapan Peraturan Mahkamah Agung (PERMA) Nomor 2 Tahun 2015 tentang Tata Cara Penyelesaian Gugatan Sederhana dalam Rangka Penyelesaian Perkara Perdata dipengadilan.

Dalam PERMA Nomor 2 tahun 2015 Tentang Tata Cara Penyelesaian Gugatan Sederhana memiliki perbedaan dengan penyelesaian perkara perdata biasa dengan tujuan mempercepat proses penyelesaian perkara, yaitu:

Pertama, perkara gugatan sederhana dicatat dalam buku register khusus, yaitu Buku Induk Register Khusus Gugatan Sederhana.

Kedua, perkara gugatan perdata sederhana diperiksa dan diputus dalam dua tingkatan oleh Pengadilan Negeri yang sama. Pada tingkat pertama, perkara diperiksa dan diputus oleh Hakim Tunggal yang penyelesaian perkara gugatan sederhana dibatasi oleh jangka waktu paling lambat 25 hari kerja Sedangkan pada tingkat upaya hukum keberatan diperiksa dan diputus oleh Hakim Majelis dalam waktu 7 hari kerja pada tingkat keberatan terhitung sejak penetapan Majelis Hakim.

Ketiga, putusan keberatan bersifat final dan mengikat serta dengan ruang lingkup pemeriksaan yang terbatas, yaitu meliputi: (a) putusan berkas gugatan sederhana; (b) permohonan keberatan dan memori keberatan; dan (c) kontra memori keberatan. Tidak ada pemeriksaan tambahan dalam keberatan dan tidak ada upaya hukum lanjutan setelah keberatan.

Keempat, proses pemeriksaan
gugatan sederhana tidak dapat
diajukan tuntutan provisi, eksepsi,
rekonvensi, intervensi, replik,
duplik, atau kesimpulan
Kelima, dalam pemeriksaan perkara gugatan sederhana hakim wajib berperan aktif dalam persidangan yang dihadiri oleh para pihak,terutama jika para pihak tidak berlatar belakang pendidikan hukum dan/atau tidak didampingi oleh kuasa hukum. Keaktifan ini ditujukan untuk: (1) memberikan penjelasan mengenai acara gugatan sederhana secara berimbang kepada para pihak;(2) mengupayakan penyelesaian perkara secara damai termasuk menyarankan kepada para pihak untuk melakukan perdamaian di luar persidangan, (3) menuntun para pihak dalam pembuktian; dan (4) menjelaskan upaya hukum yang dapat ditempuh para pihak.

Keenam, dalam ketidakhadiran Tergugat maka Hakim melanjutkan perkara dengan memeriksa dan memutus perkara tersebut tanpa kehadiran pihak Tergugat secara contradictoir yang artinya putusan tersebut berlaku dalam gugatan biasa dalam hal kedua belah pihak hadir sehingga tidak ada upaya hukum verzet terhadap Putusan tersebut namun pihak Tergugat masih dapat mengajukan upaya hukum terhadap putusan tersebut dengan mengajukan keberatan.

Hasil dari survei penelitian dengan menggunakan simple random sampling dengan populasi penelitian ini adalah semua masyarakat para pengguna layanan serta pencari keadilan pada Pengadilan Negeri Kabupaten Kediri I B didapatkan bahwa Indeks survei Penerapan PERMA No. 2 tahun 2015 Tentang Gugatan Sederhana di Pengadilan Negeri Kabupaten Kediri Kelas I B adalah sebesar $64,53 \%$ berada pada kategori "BAIK" (pada interval $62.51 \mathrm{~s} / \mathrm{d}$ 81.25). dengan rincian dari hasil survei tersebut di atas, terdiri dari empat ruang lingkup, analisis selanjutnya adalah mendeskripsikan hasil analisis terhadap keempat ruang lingkup tersebut.

Tabel Skor dan Peringkat pada survei Penerapan PERMA No.2Tahun 2015 di Pengadilan Negeri Kabupaten Kediri

\begin{tabular}{|l|l|l|c|c|}
\hline $\begin{array}{l}\text { N } \\
\text { o }\end{array}$ & Ruang Lingkup & $\begin{array}{l}\text { Rata- } \\
\text { rata }\end{array}$ & $\begin{array}{c}\text { Kate } \\
\text { gori }\end{array}$ & $\begin{array}{c}\text { Perin } \\
\text { gkat }\end{array}$ \\
\hline 1. & $\begin{array}{l}\text { pengetahuan } \\
\text { masyarakat } \\
\text { tentang PERMA } \\
\text { Nomor 2 Tahun } \\
2015\end{array}$ & 2,575 & Baik & 3 \\
\hline 2 & $\begin{array}{l}\text { tentang } \\
\text { penyelesaian } \\
\text { sengketa perdata } \\
\text { melalui mekanisme } \\
\text { gugatan sederhana } \\
\text { (PERMA Nomor } \\
\text { 2 Tahun 2015) }\end{array}$ & 2,675 & Baik & 1 \\
\hline 3 & $\begin{array}{l}\text { penyelesaian } \\
\text { perkara sesuai } \\
\text { dengan asas } \\
\text { peradilan } \\
\text { "sederhana, cepat }\end{array}$ & 2,650 & Baik & 2 \\
\hline
\end{tabular}




\begin{tabular}{|l|lr|l|l|l|}
\hline & \multicolumn{2}{|l|}{ dan biaya murah" } & & & \\
\hline 4 & materi rratan & 2,425 & kura & 4 \\
. & pada reRMA & & ng & \\
& $\begin{array}{l}\text { Nomor } \\
2015\end{array}$ & Tahun & & baik & \\
\hline
\end{tabular}

Selain mendapatkan saran-saran responden tentang prosedur penyelesaian perkara dengan gugatan sederhana maka penulis juga melakukan wawancara dengan hakim-hakim Pengadilan Negeri Kabupaten Kediri sebagai berikut:

Ibu Lila Sari,SH,MH yang mengatakan bahwa gugatan sederhana merupakan solusi yang dilakukan oleh Mahkamah Agung mengatasi permasalah yang sering dihadapi masyarakat yang sebetulnya perkara yang bisa diselesaikan secara cepat karena pembuktiannya mudah namun oleh karena prosedur beracara mulai dari tingkat pertama sampai dengan tingkat kasasi yang memakan waktu yang sangat lama dan perkara-perkara tersebut yang menjadikan penumpukan perkara di Mahkamah Agung ${ }^{6}$. Kemudian bapak Imam Santoso, SH, M.Hum menerangkan bahwa seorang Hakim didalam menyelesaikan perkara harus berperan aktif dan dapat mengatur persidangan mengingat waktunya yang singkat (dua puluh lima hari) sehingga para pihak benar-benar menggunakan waktu sebaik-baiknya, dan penyelesaian perkara gugatan melalui mekanisme gugatan sederhana sangat sesuai dengan prinsip persidangan yakni sederhana,cepat dan biaya murah namun tetap mengutamakan kualitas persidangan dengan hasil adalah mencapai keadilan dan bermanfaat sehingga dapat menyelesaikan sengketa ${ }^{7}$. sedangkan bapak Muhammad Fahmi, SH, MHum mengemukakan bahwa proses persidangan dengan tata cara gugatan sederhana benarbenar efektif dan efisien karena mengensampingkan proses-proses acara persidangan seperti replik, duplik ataupun kesimpulan yang cukup memakan waktu dan hakim yang memeriksa perkara dipermudah

\footnotetext{
6 Wawancara dengan Hakim Pengadilan Negeri Kabupaten Kediri Lila Sari,SH,MH pada tanggal 20 Maret 2017

7 Wawancara dengan Hakim Pengadilan Negeri Kabupaten Kediri Imam Santoso, SH, M.Hum pada tanggal 23 Maret 2017
}

dengan adannya pengajuan bukti khususnya untuk penggugat pada saat pengajuan gugatan sudah melampirkan bukti-bukti suratnya serta saksi-saksi yang akan diajukan demikian pula pihak tergugat yang sudah mengajukan buktibukti pada saat jawaban sehingga sebelum memeriksa dipersidangan hakim sudah mengetahui fakta-fakta hukumnya. ${ }^{8}$ Sedangkan menurut Guntur Pambudi Wijaya, $\mathrm{SH}, \mathrm{MH}$ gugatan sederhana merupakan salah satu terobosan hukum yang dibuat oleh Mahkamah Agung dalam beracara perdata di pengadilan dibandingkan apabila menggunakan mekanisme penyelesaian gugatan biasa yang didasarkan $\mathrm{HIR}$ dan $\mathrm{RBg}$ walaupun telah diatur dalam selain waktu yang cenderung lebih lama dan memakan banyak biaya karena adannya upaya hukum sampai dengan Mahkamah Agung serta beberapa aturan yang ditiadakan dalam gugatan sederhana membuat lebih mudah (sederhana) sehingga asas peradilan "Sederhana, Cepat dan Biaya ringan dapat tercapai tanpa mengurangi kepastian hukum, kemanfaatan, dan keadilan. ${ }^{9}$ Berdasarkan hasil penelitian sebagaimana diuraikan diatas maka penulis berpendapat bahwa PERMA Nomor 2 Tahun 2015 Tentang Tata Cara Penyelesaian Gugatan Sederhana khususnya di Pengadilan Negeri Kabupaten Kediri adalah efektif sebagai salah satu solusi untuk menyelesaikan perkara dengan menerapkan asas peradilan "Sederhana, Cepat dan Biaya ringan dapat tercapai dan hasilnya diterima oleh para pihak sehingga dapat menghindarkan terjadinya penumpukan perkara di Mahkamah Agung walaupun ada beberapa kelemahan seperti jumlah perkara gugatan sederhana yang masuk jauh lebih sedikit dibandingkan perkara gugatan biasa sebagai akibat kurangnya sosialisasi untuk dapat memberikan wawasan lebih kepada masyarakat secara luas terutama kepada masyarakat yang awam akan hukum agar lebih memahami tentang tatacara penyelesaian gugatan sederhana di pengadilan negeri melalui media masa maupun internet

\footnotetext{
8 Wawancara dengan Hakim Pengadilan Negeri Kabupaten Kediri Muhammad Fahmi, SH, MHum pada tanggal 23 Maret 2017

9 Wawancara dengan Hakim Pengadilan Negeri Kabupaten Kediri Guntur Pambudi Wijaya, SH, MH pada tanggal 23 Maret 2017
} 
yang lebih lanjut akan dibahas dalam faktorfaktor yang mempengaruhi penerapan terhadap Tata Cara Penyelesaian Gugatan Sederhana.

\begin{tabular}{l} 
Faktor-faktor yang mempengaruhi \\
penerapan terhadap Tata Cara \\
Penyelesaian Gugatan Sederhana \\
\multicolumn{2}{c}{ Didalam penelitian diperoleh }
\end{tabular}
beberapa faktor-faktor yang mempengaruhi penerapan terhadap Tata Cara Penyelesaian Gugatan Sederhana terutama faktor negatif yang dianggap sebagai sesuatu yang mempengaruhi kekurang keberhasilannya PERMA tersebut.

\section{Faktor Peraturan Perundang-undangan}

1. Dalam Perma Gugatan Sederhana mengenal satu bentuk upaya hukum terhadap putusan hakim, yaitu hak untuk mengajukan keberatan. Penyederhanaan jenis upaya hukum dalam gugatan sederhana mulai dari tahapan, jangka waktu pengajuan hingga proses pemeriksaan keberatan yang dimaksudkan agar proses berperkara perdata menjadi sederhana. Upaya hukum diajukan paling lambat 7 hari setelah putusan diucapkan atau setelah pemberitahuan putusan dalam hal Tergugat tidak hadir dapat memunculkan masalah hukum jika dikaitkan dengan ketentuan mengenai pengajuan upaya hukum atas putusan verstek (verzet) yang selama ini berlaku. Memang dalam hal tergugat tidak hadir pada pemeriksaan gugatan sederhana maka persidangan dilanjutkan dan diputus tanpa hadirnya tergugat akan tetapi putusan tersebut bukanlah putusan vertek melainkan putusan tersebut contradictoir yang artinya putusan tersebut berlaku dalam gugatan biasa dalam hal kedua belah pihak hadir sehingga tidak ada upaya hukum verzet terhadap putusan tersebut namun pihak Tergugat masih dapat mengajukan upaya hukum terhadap putusan tersebut dengan mengajukan keberatan. Penyederhanaan upaya hukum dalam gugatan sederhana menjadi hanya berupa keberatan tersebut dapat menimbulkan permasalahan apabila ternyata pemeriksaan keberatan terhadap putusan hakim gugatan sederhana termasuk terhadap putusan tanpa hadirnya tergugat (verstek) adalah hanya berdasarkan putusan dan berkas gugatan sederhana, permohonan keberatan dan memori keberatan serta kontra memori keberatan dan tidak diperbolehkannya dilakukan pemeriksaan tambahan, maka ada hakhak dasar tergugat yang tidak dikomodir dalam proses hukum tersebut ${ }^{10}$. Adalah asas bahwa proses pemeriksaan perkara perdata kewajiban untuk memberikan hak dan kesempatan yang sama kepada kedua belah pihak (audi et alteram partem). Kesempatan yang sama tidak saja untuk didengarkan akan tetapi juga dalam mengajukan alat-alat bukti untuk membuktikan kebenaran dalil-dalilnya. Tujuan sebagaimana maksud keberadaan upaya hukum dalam PERMA Nomor 2 Tahun 2015 tidak akan tercapai karena tidak terbukanya kesempatan kepada tergugat untuk mengajukan pembuktian atas dalil-dalil keberatan dalam memori keberatan.

2. Dalam gugatan sederhana domisili para pihak harus dalam wilayah hukum yang sama, hal ini tidak sejalan dengan hukum acara perdata menganut asas domisili tergugat (asas actor sequitur forum rei) yaitu yang berwenang mengadili suatu perkara perdata adalah Pengadilan Negeri (PN) yang wilayah hukumnya meliputi tempat tinggal tergugat ${ }^{11}$. Sehingga menurut penulis adalah cukup apabila mengajukan gugatan sederhana di Pengadilan didomisili tergugat walaupun penggugat berbeda domisili namun oleh karena penggugat adalah orang yang berkepentingan maka tidak akan sulit melakukan pemanggilan serta proses 25 hari terhitung pada saat mulai sidang pertama. Serta apabila pihak penggugat menggunakan kuasa hukum maka dapat menggunakan alamat

10 Sekti Eka Guntoro, Yang Tidak Sederhana Dari Gugatan Sederhana, https://sektiekaguntoro.wordpress.com/2016/08 /12/yang-tidak-sederhana-dari-gugatansederhana/ diunduh pada hari Kamis tanggal 2 Maret 2017 jam 10.28 wib

${ }^{11}$ Pasal 118 ayat (1) HIR 
domisili kuasa hukumnya tersebut dengan kewajiban tentunya alamat domisili kuasa hukum yang sama dengan Pengadilan yang memeriksa perkara aquo.

3. Dalam gugatan sederhana, kedua belah pihak wajib menghadiri secara langsung setiap persidangan dengan atau didampingi oleh kuasa hukum yang domisili kuasa hukum harus berada di daerah hukum pengadilan yang mengadili perkara aquo. Apabila salah satu pihak baik sebagai penggugat ataupun tergugat adalah badan hukum dan pimpinan badan hukum dapat memberikan kuasa kepada salah satu karyawan pada perusahaan tersebut dengan memperhatikan anggaran dasar dan kewajiban hadir dalam setiap persidangan adalah karyawan yang bersangkutan. Namun demikian adalah pilihan dari para pihak apakah dalam sengketa dipengadilan tersebut dirinya menggunakan jasa seorang pengacara walaupun dengan menggunakan pengacara tentunya membutuhkan biaya yang tidak sedikit. Sehingga dengan pengaturan bahwa walaupun pihak sudah menggunakan jasa pengacara namun tetap diharuskan untuk terus menghadiri persidangan maka dirinya merasa sia-sia telah membayar jasa pengacara tersebut dan tentunya mempengaruhi jumlah pengajuan gugatan perdata melalui mekanisme gugatan sederhana.

4. Dalam pemeriksaan pendahuluan apabila hakim berpendapat bahwa gugatan tidak termasuk dalam gugatan sederhana karena pembuktiannya tidak sederhana, diluar sengketa hak atas tanah dan penyelesaian sengketanya tidak dilakukan melalui pengadilan khusus maka hakim mengeluarkan penetapan yang menyatakan bahwa gugatan bukan gugatan sederhana dan terhadap penetapan tersebut tidak dapat dilakukan upaya hukum apapun. PERMA Nomor 2 Tahun 2015 tidak menjelaskan mengenai kategori ataupun kriteria pembuktian yang sederhana selain menegaskan secara tegas menyatakan bukan mengenai sengketa hak atas tanah oleh karena dalam penyelesaian sengketa tanah pembuktiannya rumit dan waktunya cukup lama serta dibutuhkan pemeriksaan setempat sehingga tentunya untuk menyelesaikan dalam waktu dua puluh lima hari kerja tidak akan tercapai.

Faktor Budaya Hukum Masyarakat

Diterbitkan PERMA Nomor 2 tahun 2015 tentang tata cara penyelesaian gugatan sederhana dengan alasan agar masyarakat mau menyelesaiakan perkaranya yang terutama perkara nilai nominalnya kecil di Pengadilan, jangan timbul persepsi dimasyarakat menyelesaikan perkara di Pengadilan ibarat melaporkan kehilangan kambing mengakibatkan sapi ikut hilang. Demikian juga kesenangan atau ketidak senangan untuk berpekara adalah bagian dari budaya hukum. Budaya hukum menentukan bagaimana sistem hukum memperoleh tempatnya yang logis dalam kerangka budaya milik masyarakat umum dan Kiranya usahausaha untuk menumbuhkan budaya hukum dapatlah mencapai hasilnya apabila proses pelembagaan telah dilakukan sehingga perlu adannya sosialisasi kepada masyarakat kecil oleh karena gugatan sederhana berorentasi pada masyarakat kecil dengan lebih meningkatkan penyuluhan-penyuluhan hukum dan haruslah dihindari ungkapan "noblesse oblige" bahwa kebijakan yang menyangkut kepentingan rakyat banyak hanya suatu elemen yang penting dalam pembuatan keputusan oleh golongan yang elit yang sedang berkuasa ${ }^{12}$.

\section{Faktor Aparat Penegak Hukum}

Dituntut kualitas hakim yang memeriksa perkara tersebut adalah mumpuni dalam mengoptimalkan waktu yang diberikan padanya untuk memutus perkara pada waktu yang sudah ditentukan namun tetap mengutamakan kualitas putusan sehingga tidak asal-asalan namun tetap mengutamakan (reasoning) pertimbangan hukum yang jelas dan cukup yang dapat diterima oleh logika hukum, karena untuk dapat membuat putusan pengadilan yang benar-benar menciptakan kepastian dan mencerminkan

12 Esmi Warasih, Pengaruh Budaya Hukum Terhadap Fungsi Hukum, Satjipto Rahardjo, 1981, Hukum Dalam Perspektif Sosial, Alumni, Bandung, h.138 
keadilan bagi para pihak yang berperkara, hakim harus mengetahui duduk perkara yang sebenarnya dan peraturan hukum yang akan ditetapkan baik peraturan hukum tertulis dalam perundang-undangan maupun peraturan hukum tidak tertulis atau hukum adat. Sehingga terhadap putusan yang tidak memenuhi ketentuan itu dikategorikan putusan yang tidak cukup pertimbangan (onvoldoende gemotiveerd).

\section{Faktor Pengetahuan Masyarakat tentang} PERMA No.2 Tahun 2015

Sebagian besar koresponden hanya mengetahui tentang gugatan sederhana namun tidak mengetahui secara spesifik tentang apa itu gugatan sederhana dan ada sekitar 3 orang yang sama sekali tidak mengetahui gugatan sederhana. Sedangkan menurut survei kualitatif yakni berdasarkan saran dari responden secara umum adalah lebih kepada sosialisasi terhadap pemahaman PERMA Nomor 2 Tahun 2015 oleh masyarakat melalui penyuluhan hukum ketengah masyarakat ataupun dengan menggunakan media internet kemudian media massa serta paflet, brosur sehingga masyarakat lebih mengenal tentang gugatan sederhana.

\section{KESIMPULAN}

1. Penerapan Peraturan Mahkamah Agung (PERMA) Nomor 2 Tahun 2015 tentang Tata Cara Penyelesaian Gugatan Sederhana dalam Rangka Penyelesaian Perkara Perdata dipengadilan menurut hasil wawancara dengan para Hakim dan para Aparatur Pengadilan didapatkan hasil bahwa prosedur gugatan sederhana sangat efektif sesuai dengan asas sederhana, cepat dan biaya ringan serta dari survei didapatkan bahwa Indeks survei Penerapan PERMA No. 2 tahun 2015 Tentang Gugatan Sederhana di Pengadilan Negeri Kabupaten Kediri Kelas I B adalah sebesar 64,53 \% berada pada kategori "BAIK" (pada interval $62.51 \mathrm{~s} / \mathrm{d} 81.25)$.

2. Faktor-faktor yang mempengaruhi penerapan terhadap Tata Cara Penyelesaian Gugatan Sederhana : a. Faktor Peraturan Perundang-undangan, b. Faktor Budaya Hukum Masyarakat, c. Faktor Aparat Penegak Hukum dan d.
Faktor Pengetahuan Masyarakat tentang PERMA No.2 Tahun 2015

\section{E. DAFTAR PUSTAKA}

Buku

Esmi Warasih, Pengaruh Budaya Hukum

Terhadap Fungsi Hukum, Satjipto

Rahardjo, 1981, Hukum Dalam

Perspektif Sosial, Alumni, Bandung, h.138

Direktorat Jenderal Badan Peradilan Umum Mahkamah Agung RI,2015, Bimbingan

Teknis Penyelesaian Perkara

Gugatan Sederhana, Direktorat Jenderal Badan Peradilan Umum Mahkamah Agung RI

Peter Mahmud Marzuki,2009, Penelitian

Hukum, Kencana Prenada Media Group, Jakarta

Jurnal

Efa Laela Fakhriah, Eksistensi Small Claim Court dalam Mewujudkan Tercapainya Peradilan Sederhana, Cepat, dan Biaya Ringan. Hasil Penelitian Mandiri tahun 2012. Dosen Fakultas Hukum Universitas Padjadjaran Bandung pada mata kuliah Hukum Acara Perdata, Hukum Penyelesaian Sengketa, Hukum Kesehatan.

Francis Ward Stephanie, Oktober 2011 "Small Claims Court the "Fast Food" of the Legal System", American Bar Assiciation Journal, Vol. 9, No. 2.

\section{Peraturan Perundang-undangan}

HIR Pasal 118 ayat (1).

Peraturan Presiden RI No 2 Tahun 2015 tentang Rencana Pembangunan Jangka Menengah Nasional (RPJMN) 20152019 BUKU I Agenda Pembangunan Nasional, Kementerian Perencenaan Pembangunan Nasional/ Badan Perencanaan Pembangunan Nasional 2014.

\section{Lain-lain}

Sekti Eka Guntoro, Yang Tidak Sederhana Dari Gugatan Sederhana, https://sektiekaguntoro.wordpress.com /2016/08/12/yang-tidak-sederhanadari-gugatan-sederhana/ diunduh pada 
hari Kamis tanggal 2 Maret 2017 jam 10.28 wib

Wawancara dengan Hakim Pengadilan Negeri Kabupaten Kediri Lila Sari,SH,MH pada tanggal 20 Maret 2017

Wawancara dengan Hakim Pengadilan Negeri Kabupaten Kediri Imam Santoso, SH, M.Hum pada tanggal 23 Maret 2017

Wawancara dengan Hakim Pengadilan Negeri Kabupaten Kediri Muhammad Fahmi, SH, MHum pada tanggal 23 Maret 2017

Wawancara dengan Hakim Pengadilan Negeri Kabupaten Kediri Guntur Pambudi Wijaya, SH, MH pada tanggal 23 Maret 2017 